Volume 2 Nomor 1 Edisi Juni 2013

ISSN 2354-7200
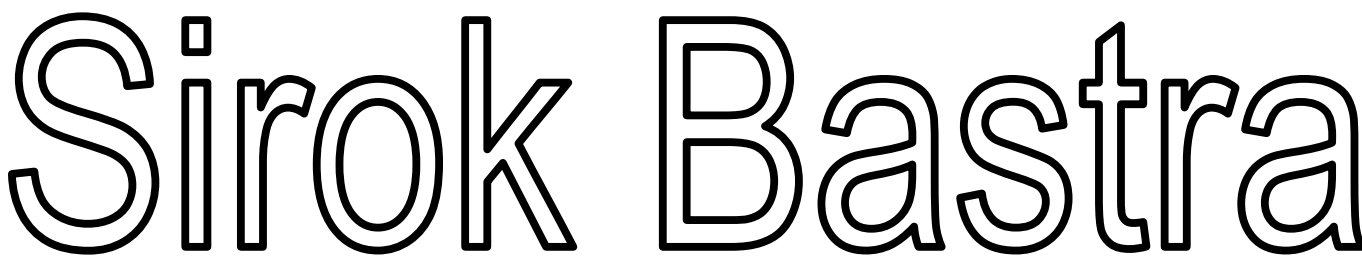

JURNAL ILMIAH KEBAHASAAN DAN KESASTRAAN

\begin{tabular}{|c|c|l|c|c|c|}
\hline $\begin{array}{c}\text { Sirok Bastra } \\
\text { Jurnal Kebahasaan dan } \\
\text { Kesastraan }\end{array}$ & Volume 2 & Nomor 1 & $\begin{array}{c}\text { Hlm. } \\
1-120\end{array}$ & $\begin{array}{c}\text { Pangkalpinang, } \\
\text { Juni 2013 }\end{array}$ & $\begin{array}{c}\text { ISSN } \\
2354-7200\end{array}$ \\
\hline
\end{tabular}

KANTOR BAHASA PROUINSI BANGKA BELITUNG 


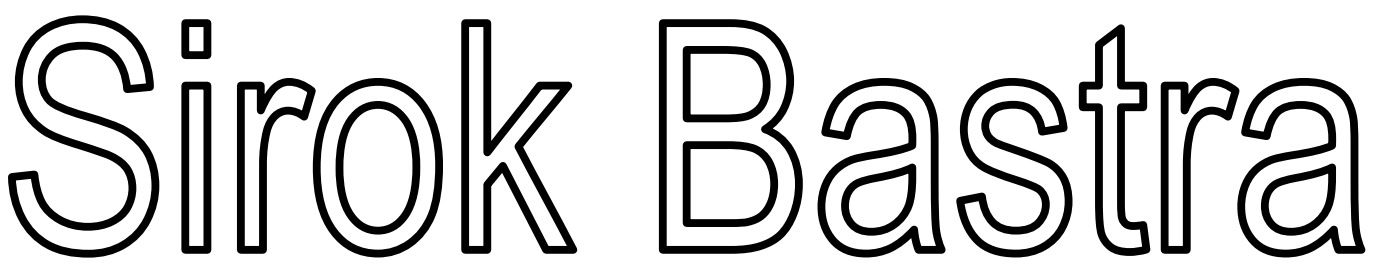

\section{JURNAL ILMIAH KEBAHASAAN DAN KESASTRAAN}

Jurnal ini merupakan wadah informasi mengenai kebahasan, kesastraan, dan pengajarannya yang memuat hasil penelitian, studi kepustakaan, dan tulisan ilmiah bidang kebahasan dan kesastraan serta pengajarannya. Sirok Bastra terbit dua kali setahun, yakni Juni dan Desember, serta terbit sejak Juni 2013.

\section{Penanggung Jawab}

Kepala Kantor Bahasa Provinsi Bangka Belitung Drs. Umar Solikhan, M.Hum.

\section{Mitra Bestari}

Prof. Dr. Agus Nuryatin, M.Hum. (Bidang Sastra dan Pengajarannya)

Prof. Amrin Saragih, Ph.D., M.A. (Bidang Bahasa dan Pengajarannya)

Dr. Felicia Nuradi Utorodewo, M.Hum. (Bidang Bahasa dan Pengajarannya)

Dr. Pujiharto, M.Hum. (Bidang Sastra dan Pengajarannya)

\section{Pemimpin Redaksi}

Rahmat Muhidin, S.S.

\section{Penyunting}

Prima Hariyanto, S.Hum.

\section{Perancang Sampul}

Feri Pristiawan, S.S.

\section{Kesekretariatan}

Khaliffitriansyah, S.Pd.

Dea Letriana Cesaria, S.Hum.

Lia Aprilina, S.Pd.

Andrian Priyatno, A.Md.

Elzam

\section{Alamat Redaksi dan Penerbit}

Kantor Bahasa Provinsi Bangka Belitung

Ruko Permata 7, Jalan Solihin G.P. Km 4, Kota Pangkalpinang, Prov. Kepulauan Bangka Belitung

Telp./Faks.: 0717-438455, Pos-el: sirokbastra@gmail.com

Pemuatan suatu tulisan dalam jurnal ini tidak berarti redaksi menyetujui isi tulisan tersebut. Isi tulisan menjadi tanggung jawab penulis. Tulisan telah ditinjau dan diulas oleh mitra bestari. Setiap karangan dalam jurnal ini dapat diperbanyak setelah mendapat izin tertulis dari penulis, redaksi, dan penerbit. 


\section{PENGANTAR}

Puji syukur ke hadirat Pemilik dan Pencipta semesta ini yang memiliki kuasa atas diri-Nya sendiri. Dialah Tuhan Yang Maha Esa yang telah memberikan rahmat dan hidayah-Nya sehingga Volume 2 Nomor 1 Jurnal Sirok Bastra Tahun 2014 dapat terbit tepat pada waktunya.

Pada edisi ini, dimuat sepuluh tulisan, yakni enam tulisan kesastraan dan empat tulisan kebahasaan. Dalam kajiannya, Anita Rima Dewi melihat kedudukan perempuan Jawa dalam keluarga — tergambar dalam novel Hati Sinden karya Dwi Rahyuningsih — dilihat dari perspektif gender. Berdasarkan penelitian, ditemukan bahwa diskriminasi gender seperti marginalisasi, stereotipe, dan subordinasi melahirkan berbagai kekerasan, yakni ekonomi, fisik, psikis, dan seksual.

Dalam kajiannya, Sarman membahas mitos buluh perindu dalam cerita rakyat Bangka. Mitos Bukit Tambun Tulang memuat struktur geografis yang menunjukkan adanya pola perjalanan hidup tokoh dalam mempertahankan hidup; struktur tekno-ekonomi yang menunjukkan adanya sistem mata pencaharian orang Bangka, antara lain berburu dan berkebun; struktur sosiologis yang menunjukan adanya hubungan sosial antara sesama manusia; dan struktur kosmologis yang menunjukkan adanya keterkaitan antara dunia nyata dan dunia gaib.

Dalam penelitiannya, Iis Afriatiningsih membahas sosok perempuan dalam karya sastra Indonesia yang diwakili oleh Nyai Ontosoroh, Pariyem, Clara yang menghadapi banyak tantangan dalam hidupnya. Hasil analisis menunjukkan bahwa sosok perempuan memiliki sikap, seperti memperjuangkan hidupnya (tergambar dalam tokoh Nyai Ontosoroh), pasrah dengan nasibnya (tergambar dalam tokoh Pariyem), dan nasibnya ada di tangan rakyat kecil (tergambar dalam tokoh Clara). Perjuangan perempuan tersebut berkaitan dengan kritik formalisme, strukturalisme, posstrukturalisme, dan posmoderenisme.

Dalam kajiannya, Asep Supriadi mengaplikasikan teori takmilah yang digagas oleh seorang pakar sastra Melayu bernama Shafie Abu Bakar pada puisi "Idul Fitri" karya Sutardji Calzoum Bachri. Hasil kajian menunjukkan bahwa puisi tersebut menggambarkan nilai-nilai keislaman dengan dimensi sufistik. Puisi itu menggambarkan perenungan eksistensi diri pada Tuhan.

Dalam kajiannya, Ch. Haris Maulana membahas tokoh dan penokohan serta nilai moral dan kekhasan yang ada dalam serial Harry Potter, khususnya seri pertama, Harry Potter dan Batu Bertuah. Nilai moral dan kekhasan yang tersirat dalam serial ini adalah sihir dapat dipelajari dan bukan faktor keturunan, kesetiakawanan, kedisipilinan, kepedulian, dan keingintahuan.

Dalam penelitiannya, Dwi Oktarina menggali aspek hibriditas dan ambivalensi yang terjadi pada tokoh Mata Hari dalam novel Namaku Mata Hari karya Remy Silado. Mata Hari, seorang agen spionase keturunan Belanda-Jawa bekerja pada banyak negara pada saat perang dunia berkecamuk. Selain itu, permainan politik tubuh Mata Hari juga menjadi sebuah hal yang menarik untuk diteliti lebih jauh. Berdasarkan penelitian, didapatkan hasil bahwa ruang-ruang pertemuan antara dua kebudayaan sama sekali tidak bisa dielakkan. Mata Hari sebagai Indo berdarah campuran Belanda-Indonesia tidak dapat melepaskan dirinya dari dua kebudayaan yang melingkupinya, Belanda maupun Indonesia.

Dalam kajiannya, Maria Christa Istiana Kamagi membahas struktur kalimat dan keterbacaan pada buku teks pelajaran bahasa Indonesia. Berdasarkan penelitian, ditemukan kalimat tunggal perluasan subjek, predikat, objek, dan pelengkap, kalimat tunggal perluasan keterangan, kalimat majemuk setara, kalimat majemuk bertingkat, kalimat majemuk bersusun, dan kalimat taklengkap. Selain menjelaskan struktur kalimat yang ada, penelitian ini juga mencoba menganalisis keterbacaan dilihat dari jumlah kata yang digunakan dalam kalimat tersebut. Hasil yang didapat adalah terdapat beberapa kalimat yang masih masuk kategori kalimat sulit dan sangat sulit dipahami.

Dalam kajiannya, Achril Zalmansyah membahas hasil Uji Kemahiran Berbahasa Indonesia (UKBI) guru dan siswa SMP di Kabupaten Lampung Utara. Data yang diperoleh menunjukkan bahwa sebagian besar peserta memperoleh nilai antara 300-400 yang berarti cukup baik. Dengan demikian, dapat dikatakan bahwa UKBI 
merupakan alat uji yang dapat digunakan untuk mengukur penguasaan bahasa Indonesia seorang guru serta penggunaan bahasa Indonesia yang baik dan benar oleh siswa.

Dalam kajiannya, Prima Hariyanto membahas kata berinfiks -er- dalam bahasa Indonesia. Korpus data penelitian ini adalah Kamus Besar Bahasa Indonesia Edisi Ketiga. Berdasarkan penelitian yang dilakukan, ditemukan 62 kata berinfiks -er- yang terdiri dari 14 jenis kelompok makna. Selain memaparkan kata berinfiks yang ada, penelitian ini juga mencoba memaparkan metode pendefinisian lema kata berinfiks yang -er-bermakna 'sama dengan bentuk dasarnya' dalam Kamus Besar Bahasa Indonesia.

Dalam penelitiannya, Hotnida Novita Sary mengkaji perbedaan bentuk verba yang terdapat dalam bahasa Melayu Tinggi dan bahasa Melayu Rendah yang terdapat dalam Injil Matius terjemahan Klinkert. Peneliti mengunduh data dari laman sabda.org. Kedua versi Injil Matius ini kemudian dibandingkan dan dicatat satu ayat dengan ayat yang sama. Hasil pencatatan inilah yang dianalisis. Hasil yang didapatkan dari penelitian ini adalah ragam bahasa Melayu Tinggi cenderung menggunakan bentuk berimbuhan, sedangkan bahasa Melayu Rendah cenderung menggunakan bentuk dasar.

Kami mengucapkan terima kasih kepada para penulis yang telah bersedia menerbitkan karya mereka pada edisi ini. Para penulis merupakan peneliti, pakar, dosen, siswa, dan mahasiswa dari berbagai sekolah, perguruan tinggi, dan instansi. Terima kasih juga kami sampaikan kepada para mitra bestari kami yang telah memberi ulasan terhadap tulisan-tulisan yang masuk ke redaksi.

Demi memenuhi keberagaman isi dan penulis, Sirok Bastra membuka kesempatan bagi para peneliti dan penulis menyampaikan hasil penelitian dan pemikiran mutakhir dalam bidang kebahasaan, kesastraan, dan pengajarannya.

Pangkalpinang, Juni 2014

Tim Redaksi 


\section{UCAPAN TERIMA KASIH UNTUK MITRA BESTARI}

Redaksi Sirok Bastra mengucapkan terima kasih kepada para mitra bestari yang telah meninjau, menimbang, dan mengulas makalah-makalah yang diterbitkan dalam Sirok Bastra Volume 2 Nomor 1, edisi Juni 2014, yakni

Prof. Dr. Agus Nuryatin, M.Hum.

Bidang Sastra dan Pengajarannya

Universitas Negeri Semarang

Semarang, Jawa Tengah

Prof. Amrin Saragih, Ph.D., M.A.

Bidang Bahasa dan Pengajarannya

Universitas Negeri Medan

Medan, Sumatra Utara

Dr. Felicia Nuradi Utorodewo, M.Hum.

Bidang Bahasa dan Pengajarannya

Universitas Indonesia

Depok, Jawa Barat

\section{Dr. Pujiharto, M.Hum.}

Bidang Sastra dan Pengajarannya

Universitas Gadjah Mada

Yogyakarta, Daerah Istimewa Yogyakarta 


\section{DAFTAR ISI}

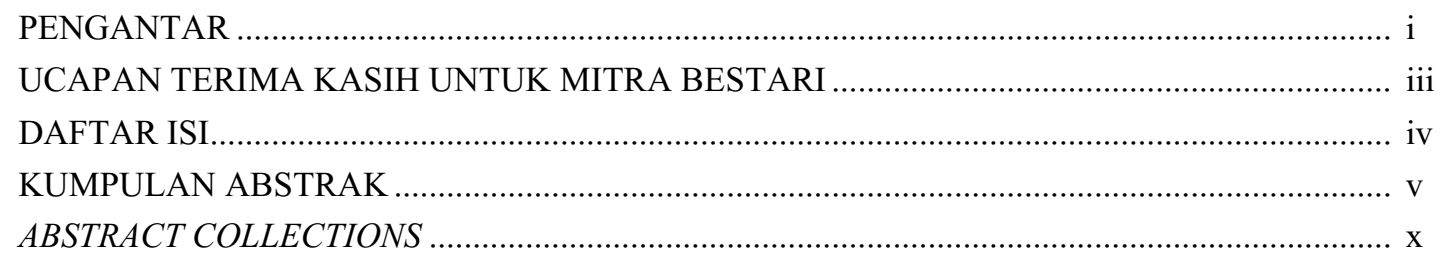

KEDUDUKAN PEREMPUAN JAWA DALAM NOVEL HATI SINDEN KARYA DWI RAHYUNINGSIH DILIHAT DARI PERSPEKTIF GENDER

(The Position of Javanese Women Based on Gender Perspective in Hati Sinden, a Novel by Dwi Rahyuningsih)

Anita Rima Dewi $1-15$

MITOS DALAM CERITA “BUKIT TAMBUN TULANG”

(Myth in "Bukit Tambun Tulang" Story)

Sarman. $17-24$

SOSOK PEREMPUAN DARI ZAMAN KE ZAMAN DALAM KARYA SASTRA INDONESIA: STUDI KASUS TOKOH NYAI ONTOSOROH, PARIYEM, DAN CLARA (Figure of Women from Time to Time in Indonesian Literary Works: A Case Study of Nyai Ontosoroh, Pariyem, and Clara)

Iis Afriatiningsih $25-33$

MEMAHAMI PUISI "IDUL FITRI" DENGAN TEORI TAKMILAH

(Understanding the Poetry "Idul Fitri” by Using Theory of Takmilah)

Asep Supriadi $35-44$

NILAI DAN KEKHASAN SERIAL HARRY POTTER (KAJIAN HARRY POTTER 1: HARRY POTTER DAN BATU BERTUAH)

(Value and Uniqueness of Harry Potter Series [A Study of Harry Potter 1: Harry Potter and The Sorcerers Stone])

Ch. Haris Maulana $45-52$

HIBRIDITAS DAN POLITIK TUBUH DALAM NOVEL NAMAKU MATA HARI KARYA REMY SILADO: SEBUAH TINJAUAN POSKOLONIAL

(Hybridity and Body Politic in Namaku Mata Hari, A Novel Written by Remy Silado: A Postcolonial Study)

Dwi Oktarina $53-61$

STRUKTUR DAN KETERBACAAN KALIMAT PADA BUKU TEKS PELAJARAN BAHASA INDONESIA

(Sentence Structure and Readability in Indonesian Textbook)

Maria Christa Istiana Kamagi. $63-78$ 
UJI KEMAHIRAN BERBAHASA INDONESIA (UKBI) BAGI GURU DAN SISWA SEKOLAH MENENGAH PERTAMA SE-LAMPUNG UTARA

(Indonesian Proficiency Test [UKBI] for Teacher and Junior High School Students All Lampung Utara)

Achril Zalmansyah

KATA BERINFIKS -ER- DALAM BAHASA INDONESIA

(-er- Infixes Words in Indonesian)

Prima Hariyanto

$89-103$

PERBEDAAN BENTUK VERBA PADA BAHASA MELAYU TINGGI DAN BAHASA

MELAYU RENDAH: STUDI KASUS INJIL MATIUS TERJEMAHAN KLINKERT

(Verb Form of Differences in Language Malay Malay Language High and Low: Case Study of The Gospel of Matthew Klinkert Translations)

Hotnida Novita Sary .... $105-120$ 
Anita Rima Dewi: Kedudukan Perempuan Jawa dalam Novel Hati Sinden Karya ...

\title{
KEDUDUKAN PEREMPUAN JAWA DALAM NOVEL HATI SINDEN KARYA DWI RAHYUNINGSIH DILIHAT DARI PERSPEKTIF GENDER
}

\author{
The Position of Javanese Women Based on Gender Perspective in Hati Sinden, a Novel by Dwi \\ Rahyuningsih
}

Anita Rima Dewi

Fakultas Ilmu Pengetahuan Budaya, Universitas Indonesia

Kampus Baru UI Depok, Jawa Barat

Pos-el: anitarimadewi@gmail.com

(diterima 14 Maret 2014, disetujui 27 Mei 2014, revisi terakhir 11 Juni 2014)

\begin{abstract}
Abstrak
Masyarakat Jawa merupakan penganut bentuk dasar sistem terminologi bilateral dan generasional yang menyamaratakan kedudukan ayah dan ibu. Namun, pada kenyataannya tetap saja ada perbedaan mengenai pola persaudaraan ini yaitu pembedaan dalam senioritas dan jenis kelamin. Dalam budaya Jawa pun dikenal istilah kanca wingking bagi perempuan. Oleh karena itu, penelitian ini akan melihat kedudukan perempuan Jawa dalam keluarga yang tergambar dalam novel Hati Sinden karya Dwi Rahyuningsih dilihat dari perspektif gender. Metode yang digunakan dalam penelitian ini adalah deskriptif analitis. Dari penelitian ini, ditemukan bahwa diskriminasi gender seperti marginalisasi, stereotipe, dan subordinasi melahirkan berbagai kekerasan ekonomi, fisik, psikis, dan seksual.
\end{abstract}

Kata kunci: gender, bilateral, generasional, kanca wingking, Jawa

\begin{abstract}
The Javanese follow the basic rules of bilateral and genarational terminology system which balance the position of men and women in society. However, there is still differentiation found in this type of family pattern, which is the differentiation in seniority and gender. There is also kanca wingking terminology for women raised in Javanese culture. Therefore, this research analyzes the position of women in Javanese families based on gender perspective illustrated in Hati Sinden, a novel written by Dwi Rahyuningsih. This research, using analytical descriptive method, finds out that the gender discrimination such as marginalization, stereotyping, and subordination often result in economic, physic, psychological, and sexual violence.
\end{abstract}

Keywords: gender, bilateral, generational, kanca wingking, Java

\section{PENDAHULUAN}

\subsection{Latar Belakang}

Karya sastra merupakan sebuah konstruksi yang menggunakan bahasa sebagai media penyampaiannya. Melalui bahasalah pembaca dapat mengetahui ide-ide atau gagasan yang disampaikan oleh pengarang. Namun, tidak semua ide atau gagasan pengarang dapat tersampaikan dengan baik kepada para pembaca karena kadang gagasan tersebut dapat berupa gagasan tersirat yang harus digali lebih dalam oleh si pembaca. Selain itu, interpretasi pembaca terhadap sebuah karya sastra pun dapat berbeda-beda tergantung sudut pandang dan faktor-faktor baik internal maupun eksternal yang dimiliki oleh pembaca.
Sastra banyak menampilkan gambaran kehidupan dalam sebuah konstruksi sosial masyarakat. Hal ini berarti karya sastra mencakup hubungan antarmakhluk hidup, antarmasyarakat, masyarakat dengan orang-seorang, dan antarperistiwa yang terjadi dalam batin seseorang. Karya sastra pun kadang menjadi perwakilan pada zamannya. Oleh karena itu, ide-ide segar dari sebuah karya sastra terus bergulir dari waktu ke waktu.

Pada hakikatnya setiap manusia diciptakan berpasang-pasangan, laki-laki dan perempuan. Manusia, baik laki-laki maupun perempuan, diciptakan dengan derajat yang sama oleh Tuhan. Kalaupun memiliki bentuk dan fungsi yang berbeda, 
hal itu agar keduanya saling melengkapi. Namun, pada kenyataannya sering terjadi perubahan peran dan status keduanya dalam masyarakat yang akhirnya berujung pada ketimpangan antara laki-laki dan perempuan.

Dalam masyarakat pun kadang terjadi kesimpangsiuran antara konsep gender dan seks atau yang disebut dengan "buta gender (gender blind) yaitu kondisi atau keadaan seseorang yang tidak memahami pengertian atau konsep gender karena ada perbedaan kepentingan laki-laki dan perempuan" (Sasongko, 2009:8). Buta gender (gender blind) tersebutlah yang juga membuat berkembangnya ketimpangan peran dan status antara laki-laki dan perempuan di masyarakat.

Gender berbeda dengan seks. Gender adalah perbedaan peran, fungsi, dan tanggung jawab antara laki-laki dan perempuan yang merupakan hasil konstruksi sosial dan dapat berubah sesuai dengan perkembangan zaman, sedangkan seks adalah perbedaan jenis kelamin yang ditentukan secara biologis (Sasongko, 2009:6). Dalam Women's Studies Encyclopedia dijelaskan bahwa gender adalah suatu konsep kultural yang berupaya membuat pembedaan dalam hal peran, perilaku, mentalitas, dan karakteristik emosional antara laki-laki dan perempuan yang berkembang dalam masyarakat.

Membahas permasalahan gender berarti membahas permasalahan perempuan dan juga lakilaki dalam kehidupan masyarakat. Pembahasan masalah ini telah banyak diangkat melalui karya sastra seperti yang telah diungkapkan di atas. Salah satu novel terbitan tahun 2011 ini yang mengangkat tema gender dan menarik hati peneliti adalah novel Hati Sinden karya Dwi Rahyuningsih. Novel ini berkisah mengenai perjuangan hidup seorang perempuan Jawa yang bergelut dengan budaya Jawa yang membentuknya. Novel ini membicarakan masalah ketidakadilan gender yang dialami oleh tokoh Sayem atau Slumpring akibat kungkungan adat yang menjeratnya.

Perbedaan gender yang digambarkan melalui novel ini telah melahirkan ketidakadilan gender yang telah terbentuk secara kultural. Dalam penelitian ini, akan dibahas masalah kedudukan perempuan Jawa yang diwakili oleh tokoh Sayem sebagai anak atau cucu, istri, dan menantu dalam persfektif gender serta melihat keterkaitan antara kedudukan perempuan Jawa dan ketidakadilan gender yang dialami tokoh Sayem. Selain itu, ketidakadilan gender yang ditimbulkan akibat pengatasnamaan peraturan adat pun menjadi salah satu pertimbangan dalam menganlisis novel ini.

\subsection{Perumusan Masalah}

Masalah yang akan dibahas dalam makalah ini adalah sebagai berikut.

1. Bagaimana kedudukan perempuan Jawa sebagai anak atau cucu, istri, dan menantu yang diwakili oleh tokoh Sayem dalam novel Hati Sinden karya Dwi Rahyuningsih dilihat dari perspektif gender?

2. Bagaimana keterkaitan antara budaya Jawa dan ketidakadilan gender yang diterima oleh tokoh Sayem dalam novel Hati Sinden karya Dwi Rahyuningsih?

\subsection{Tujuan Penelitian}

Adapun tujuan yang dicapai dalam penelitian ini adalah sebagai berikut.

1. Menjelaskan kedudukan perempuan Jawa sebagai anak atau cucu, istri, dan menantu yang diwakili oleh tokoh Sayem dalam novel Hati Sinden karya Dwi Rahyuningsih dilihat dari perspektif gender.

2. Menjelaskan keterkaitan antara budaya Jawa dan ketidakadilan gender yang dialami oleh tokoh Sayem dalam novel Hati Sinden karya Dwi Rahyuningsih.

\subsection{Manfaat Penelitian}

Penelitian ini tidak hanya dapat menambah dan melengkapi khazanah kajian gender atau kajian wanita, tetapi juga dapat menjadi suatu analisis gender yang melihat dari segi kedudukan perempuan Jawa dalam keluarga sehingga masyarakat lebih mengerti dan menghargai makna kedudukan perempuan Jawa dalam sebuah keluarga. Perempuan tak lagi dianggap sebagai kanca wingking yang berkutat di antara sumur, dapur, dan kasur. Selain itu, penelitian ini juga diharapkan mampu menjadi sebuah alternatif maupun referensi dalam penerapan budaya Jawa masa kini. Penelitian ini juga dapat dijadikan sebuah sumber atau rujukan untuk penelitian-penelitian selanjutnya mengenai gender yang terkait masalah budaya suatu 
daerah. Dengan demikian, pengkajian tentang wanita, terutama mengenai ketidakadilan gender dapat terus diperbaharui dengan mempertimbangkan hal lain seperti budaya suatu daerah.

\subsection{Metode Penelitian}

Metode yang dipakai dalam penelitian ini adalah metode deskriptif analitis. Metode ini dilakukan dengan cara mencari dan menentukan bahan, lalu mendeskripsikan fakta-fakta yang kemudian disusul dengan menganalisis. Bahan penelitian ini adalah novel Hati Sinden karya Dwi Rahyuningsih. Selanjutnya akan dijabarkan dan dianalisis mengenai ketidakadilan gender yang terjadi pada tokoh Sayem dalam novel tersebut. Tokoh Sayem dan tokoh-tokoh lainnya yang berhubungan dengan analisis yang ada akan dianalisis dengan menggunakan perspektif gender serta pendekatan ekstrinsik dengan mengaitkan hal-hal sosial dan kultural yang ada pada masyarakat Jawa, seperti adat dan aturan yang dianut. Pendekatan ekstrinsik juga diperlukan untuk mendukung dan memudahkan pemahaman saya mengenai gagasan yang disampaikan si pengarang.

\section{KAJIAN TEORI}

\subsection{Konsep Gender}

Dalam memahami konsep gender, harus dibedakan antara kata gender dengan kata seks (jenis kelamin). Pengertian jenis kelamin merupakan pensifaran atau pembagian dua jenis kelamin manusia yang ditentukan secara biologis yang melekat pada jenis kelamin tertentu, misalnya laki-laki memiliki penis, jakala (kala menjing), dan memproduksi sperma, sedangkan perempuan memiliki alat reproduksi seperti rahim, memproduksi telur, memiliki vagina, dan mempunyai alat menyusui. Semua itu secara permanen merupakan ketentuan biologis yang tidak dapat diubah dan merupakan kodrat Tuhan (Fakih, 1997:8). Gender adalah suatu sifat yang melekat pada laki-laki maupun perempuan yang dikonstruksi secara sosial maupun kultural. Gender merupakan semua hal yang dapat dipertukarkan antara sifat perempuan dan laki-laki yang bisa berubah dari waktu ke waktu serta berbeda dari tempat satu dengan tempat lainnya, maupun berbeda dari satu kelas dengan kelas yang lain (Fakih, 1997:8-9).

Menurut Bahsin (2001), gender adalah hasil konstruksi manusia dan budaya dalam suatu masyarakat. Gender merupakan perbedaan laki-laki dan perempuan berdasarkan budaya, adat, dan konvensi yang terbentuk dalam masyarakat. Gender merupakan sistem peran dan hubungan antara pria dan wanita yang tidak ditentukan oleh data biologis, melainkan lingkungan sosial, politis, dan ekonomis.

\subsection{Bentuk Ketidakadilan Gender}

\subsubsection{Marginalisasi}

Menurut Fakih (1997:14), proses marginalisasi yang mengakibatkan kemiskinan banyak sekali terjadi dalam masyarakat dan negara yang menimpa kaum laki-laki dan perempuan. Namun, ada salah satu bentuk pemiskinan atas satu jenis kelamin tertentukhususnya perempuan - disebabkan oleh gender. Marginalisasi terhadap perempuan sudah terjadi sejak di rumah tangga dalam bentuk diskriminasi atas anggota keluarga yang laki-laki dan perempuan. Marginalisasi juga diperkuat oleh adat istiadat maupun tafsir keagamaan, seperti yang banyak terjadi di antara suku-suku di Indonesia.

\subsubsection{Stereotipe}

Fakih (1997:16) mengatakan stereotipe adalah pelabelan atau penandaan terhadap kelompok tertentu. Perempuan disosialisasikan dan diasuh secara berbeda dengan laki-laki. Hal ini pun sesuai dengan pendapat Morris dalam buku Perempuan, Kesetaraan, dan Keadilan karya Sihite (2007:203) yang juga menunjukkan adanya social expectation (ekspektasi sosial) yang berbeda terhadap anak perempuan dan laki-laki. Sejak dini anak perempuan diasosiasikan bertindak lembut, tidak agresif, halus, tergantung, pasif, dan bukan pengambil keputusan. Sebaliknya laki-laki diasosiasikan agresif, aktif, mandiri, pengambil keputusan, dan dominan.

\subsubsection{Subordinasi}

Pandangan gender dapat menimbulkan subordinasi terhadap perempuan. Anggapan bahwa perempuan itu irrasional atau emosional sehingga perempuan tidak dapat memimpin berakibat munculnya sikap yang menempatkan perempuan pada posisi yang tidak 
Anita Rima Dewi: Kedudukan Perempuan Jawa dalam Novel Hati Sinden Karya ...

penting (Fakih, 1997:15-16). Menurut Sihite (2007: 203-204) pun anggapan seperti itulah yang akhirnya terinternalisasi begitu kuat sehingga dianggap sebagai sesuatu yang bersifat taken for granted dan membawa implikasi luas yang mencerminkan posisi perempuan yang lebih subordinat, sedangkan laki-laki lebih superior. Subordinasi itu sendiri pun terjadi dalam segala macam bentuk yang berbeda dari tempat ke tempat dan dari waktu ke waktu.

Selanjutnya, pada posisi perempuan yang subordinat ini muncullah ketidakadilan gender yang antara lain diekspresikan dalam bentuk tindak kekerasan, baik kekerasan yang dijalankan sebagaimana sifatnya maupun kekerasan dalam selimut kasih sayang yang menipu. Kekerasan sendiri, menurut A. Nunuk. P. Murniati (2004:222), adalah perilaku atau perbuatan yang terjadi dalam relasi antarmanusia, baik individu maupun kelompok, yang dirasa oleh salah satu pihak sebagai satu situasi yang membebani, membuat berat, tidak menyenangkan, dan tidak bebas. Situasi yang disebabkan oleh tindak kekerasan ini membuat pihak lain sakit, baik secara fisik maupun psikis serta rohani. Selain itu, Walker pun dalam buku Benih Bertumbuh karya Fentiny Nugroho (2000:100), mengembangkan teori siklus kekerasan yang terdiri atas tiga tahap, yaitu pembentukan ketegangan, tindakan kekerasan, dan bulan madu atau rasa cinta dan penyesalan. Ketiga siklus itu terus berputar tanpa henti sampai ada salah satu pihak yang mengambil keputusan seperti perempuan yang akhirnya meninggalkan suaminya setelah tahap pembentukan ketegangan terlalu sering dan lama, sementara tahap bulan madu menjadi jarang atau tidak ada lagi.

Menurut Fathul Djannah (2003:14-15), kekerasan terhadap perempuan dalam rumah tangga (Domestic Violence) terbagi dalam empat bentuk yang meliputi kekerasan ekonomi, fisik, psikis, dan seksual.

\subsection{Sosiologi Sastra}

Teori sosiologi sastra sebenarnya sudah diketengahkan orang sejak sebelum Masehi. Sudah sewajarnya apabila sastra yang pada awal perkembangan tidak bisa dipisahkan dari kegiatan sosial, dianggap sebagai unsur kebudayaan yang dapat memengaruhi dan dipengaruhi masyarakatnya. Menurut Plato, segala yang ada di dunia ini sebenarnya hanya merupakan tiruan dari kenyataan tertinggi yang berada di dunia gagasan. Dalam dunia gagasan itu ada satu manusia, dan semua manusia yang ada di dunia ini adalah tiruan dari manusia yang berada di dunia gagasan tersebut (Damono, 1978:16).

Menurut Wellek dan Warren dalam buku Sosiologi Sastra (Damono, 1978:9), pendekatan yang umum dilakukan terhadap hubungan sastra dan masyarakat adalah mempelajari sastra sebagai dokumen sosial, sebagai potret kenyataan sosial. Memang ada semacam potret sosial yang dapat ditarik dari karya sastra. Karya sastra yang menampilkan cermin masyarakat tampak lebih dominan terdapat pada novel daripada puisi atau drama. Menurut Mahayana (2005:338 -339) khusus mengenai novel, ada kecenderungan masalah tersebut berkaitan dengan warna lokal atau gambaran tradisi masyarakat tertentu. Dalam penggambaran warna lokal tersebut, di dalam novel yang menjadi objek penelitian ini, diangkat unsur budaya dalam masyarakat Jawa. Selain itu pun, difokuskan pada kedudukan perempuan dalam keluarga Jawa.

Menurut Geertz (1983:19—20), masyarakat Jawa menganut bentuk dasar sistem terminologi bilateral dan generasional bersisi dua dan turun temurun. Artinya bahwa istilah-istilah keluarga tersebut sama, baik saudara perangkainya ibu atau ayah. Namun, pada kenyataannya tetap saja ada pembedaan lain mengenai pola persaudaraan ini yaitu pembedaan dalam senioritas dan jenis kelamin. Pembedaan senioritas itu dipakai untuk merinci kategori-kategori keturunan dalam golongan senior dan junior, misalnya orangtua dan anak, sedangkan pembedaan jenis kelamin dipakai untuk merinci kategori-kategori berdasarkan jenis kelamin dalam golongan laki-laki dan perempuan, misalnya ayah dan ibu. 
Anita Rima Dewi: Kedudukan Perempuan Jawa dalam Novel Hati Sinden Karya ...

Tabel Kerangka Terminologi Keluarga Jawa (Geertz, 1983: 21).

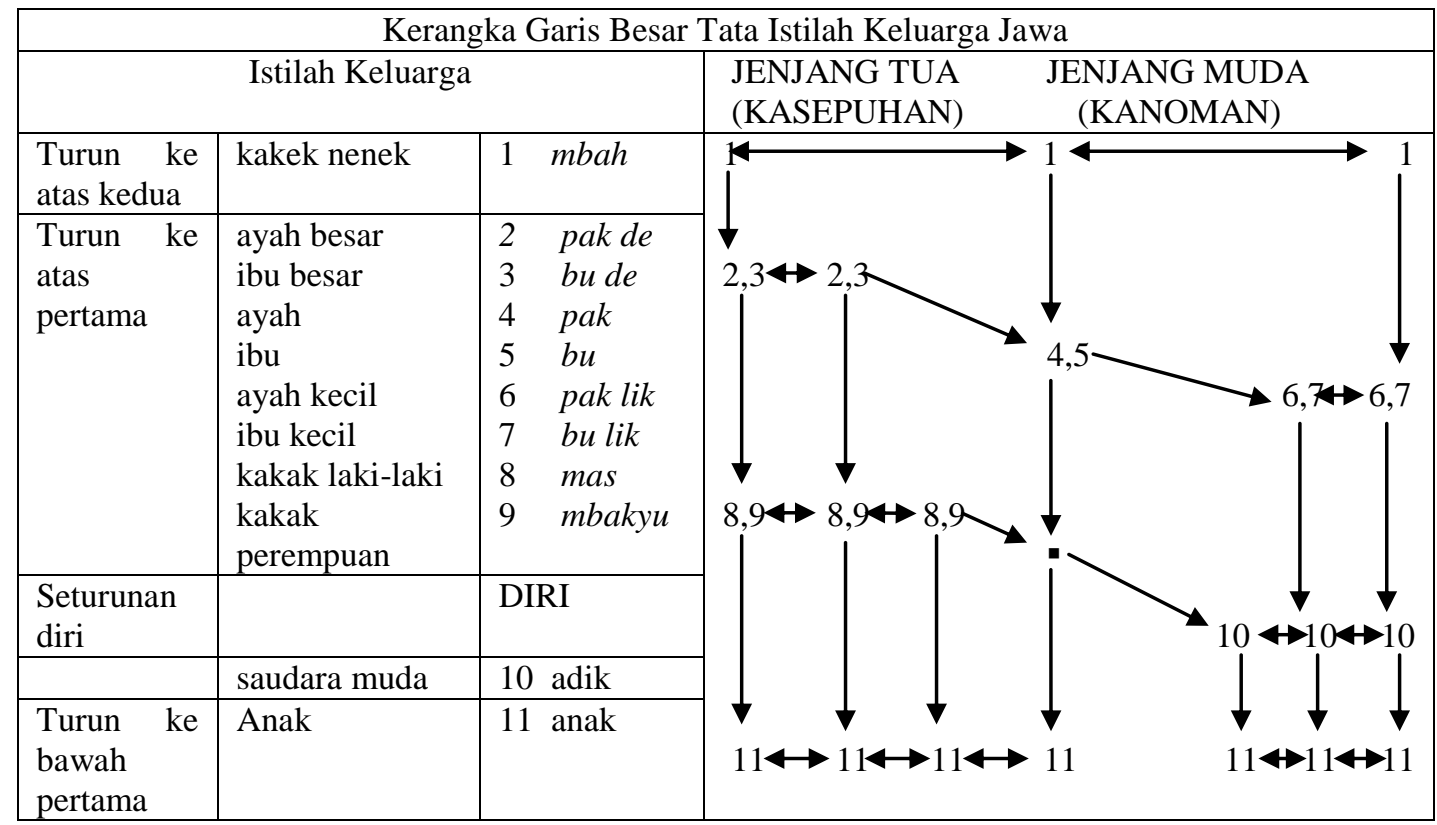

Pembedaan senioritas dipakai untuk merinci kategori-kategori keturunan ke dalam golongan junior dan senior. Hal ini terlihat dari garis panah menurun dan bagian jenjang yang terdiri dari jenjang tua (kesepuhan) dan jenjang muda (kanoman), sedangkan jenis kelamin memperlihatkan kedudukan yang sejajar. Namun, kategori jenis kelamin pun tetap dipisahkan oleh tanda koma yang terdiri atas bagian kiri dan kanan. Kiri yang berarti superordinat dan kanan yang berarti subordinat seperti halnya senior dan junior.

Adat istiadat pada masyarakat Jawa biasa dikenal dengan sebutan tata krama atau "unggah-ungguh". Koentjaraningrat (1984: 12) membedakan arti "unggah-ungguh" dengan sopan santun. Walaupun keduanya termasuk dalam pengertian tradisi atau adat, tetapi unggah-ungguh terkait dengan norma tingkah laku yang berhubungan dengan peran. Oleh karena itu, setiap orang Jawa harus mengetahui peran yang diembannya. Peran yang paling terlihat jelas yaitu peran atau kedudukan antara laki-laki dan perempuan. Dalam masyarakat Jawa yang mengenal terminologi bilateral tetapi juga menganut konsep paternalistik, perempuan dianggap sebagai kanca wingking yang hanya berkutat masalah sumur, dapur, dan kasur.

\section{PEMBAHASAN}

Perbedaan gender yang terjadi sesungguhnya melahirkan berbagai ketidakadilan, baik bagi kaum laki-laki dan terutama kaum perempuan. Ketidakadilan gender tersebut kemudian menjelma menjadi beberapa bentuk seperti marginalisasi, subordinasi, stereotipe, kekerasan, dan beban ganda. Bentuk-bentuk ketidakadilan gender yang dianalisis penulis dalam makalah ini dibatasi hanya marginalisasi, stereotipe, dan subordinasi yang melahirkan kekerasan. Bentuk-bentuk ketidakadilan gender tersebut yang dialami oleh tokoh Sayem menunjukkan kedudukannya sebagai perempuan Jawa dalam keluarga, baik sebagai anak atau cucu, menantu, maupun istri.

\subsection{Anak atau Cucu}

\subsubsection{Marginalisasi}

Lahirnya marginalisasi diperkuat oleh adat seperti yang dialami oleh tokoh Sayem dalam novel ini. Ketika Marta Prawira, Bapak Sayem, meninggal dunia, ia mewariskan gamelan miliknya yang terdiri dari kendang dan rebab kepada Wesi, anak pertamanya, gerobak yang merupakan alat transportasi untuk mengangkut alat-alat gamelan pada masa itu kepada Sugi, anak keduanya, dan berwasiat kepada Simbah untuk mencarikan jodoh Sayem (hlm. 124 dan 126). 
Anita Rima Dewi: Kedudukan Perempuan Jawa dalam Novel Hati Sinden Karya ...

Hal itu memperlihatan kedudukan Sayem sebagai seorang perempuan dalam keluarga bahwa ketika ayahnya meninggal dunia, bukan warisan yang didapatnya seperti kedua saudara laki-lakinya, tetapi wasiat perjodohan. Laki-laki merupakan calon kepala keluarga. Oleh karena itulah, mereka harus diberikan modal untuk menafkahi keluarganya kelak, sedangkan perempuan jika menikah akan mengikuti dan dinafkahi oleh suami. Oleh karena itu, Ayah Sayem hanya berwasiat untuk menjodohkan Sayem.

Meskipun mencoba menolak, Sayem harus tetap menuruti perjodohan tersebut walaupun berdampak buruk terhadap psikisnya karena ia selalu menekan setiap keinginan dan pendapatnya di hadapan Simbah. Perjodohan itu menjadi bukti peminggiran terhadap perempuan. Jika orang tua tersebut tidak mampu memberikan warisan kepada semua anaknya, anak perempuanlah yang harus mengalah. Anak perempuan dijodohkan dengan orang yang berkecukupan dan dapat membiayai hidupnya kelak seolah sebagai pengganti harta warisan yang tak mampu diberikan oleh orang tuanya.

\subsubsection{Stereotipe}

Stereotipe atau pelabelan yang diajarkan atau dituntut Simbah kepada Sayem sesuai dengan etika kebatinan Jawa menurut Neils Mulder (2001:67) yaitu sepi ing pamrih yang berarti tidak mementingkan diri sendiri. Selanjutnya prinsip etika kebatinan tersebut dilaksanakan melalui perwujudan nilai-nilai seperti nerima (mensyukuri hidup seperti adanya), waspadaeling (terus-menerus mengingat), dan andhap-asor (rendah hati).

Pada usianya yang masih kanak-kanak bahkan Simbah selalu menuntut agar Sayem dapat berpikiran dewasa. Ia diharuskan membunuh setiap keinginannya untuk memiliki mainan ataupun baju baru seperti teman-temannya. Hal ini menunjukkan bahwa melalui stereotipe, Sayem mendapatkan kekerasan psikis yang dilakukan oleh Simbah. Sayem dituntut menjadi perempuan yang dapat menerima setiap keadaan hidup serta selalu mengingat dan meminta kepada Tuhan jika menginginkan sesuatu.

Simbah juga mengajarkan Sayem agar selalu bersikap andhap-asor, yakni sikap hormat dengan menunjukkan diri berkedudukan lebih rendah dari yang lain dan berlomba-lomba untuk mengalah. Andhap-asor juga dapat diartikan sebagai sikap yang diambil untuk menyesuaikan derajat masing-masing (Handayani dan Novianto, 2004:63). Oleh karena itu, Simbah sangat marah ketika Sayem melakukan penolakan terhadap suami pertamanya yaitu Tugiman Blanggreng. Simbah merasa seolah-olah Sayem seperti perempuan miskin yang sombong dan tak tahu diri.

Selain itu, setreotipe-stereotipe mengenai perempuan Jawa lainnya juga Simbah ajarkan kepada Sayem seperti perempuan Jawa tidak baik keluar sore ataupun malam hari karena perempuan ibarat bunga atau kembang. Perempuan juga harus pandai merawat dirinya agar dapat menarik di mata laki-laki karena perempuan yang telah beranjak dewasa merupakan perempuan yang telah siap dinikahkan. Sayem yang dibekali oleh Simbah mengenai pemahamanpemahaman tersebut hanya mempu menuruti dan menjalankannya karena Simbah merupakan pengganti orang tua baginya yang setiap perkataannya wajib dituruti.

\subsubsection{Subordinasi}

Subordinasi atau penomorduaan terhadap perempuan memunculkan ketidakadilan gender yang dapat diekspresikan dalam bentuk kekerasan. Posisi Sayem yang subordinat dalam keluarga yaitu sebagai cucu dan anak perempuan mengharuskan Sayem menuruti semua perintah Simbah terutama mengenai perjodohan

\subsubsection{Kekerasan Ekonomi}

Posisi Sayem yang subordinat dalam keluarga ternyata memberikan dampak kekerasan ekonomi padanya. Penolakannya terhadap Tugiman Blanggreng membuat Simbah begitu marah terhadapnya sehingga Sayem perlu mengambil sikap untuk meluluhkan hati Simbah yaitu dengan cara memberikan uang pada Simbah untuk membantu perekonomian keluarga. Segala pekerjaan rela Sayem lakukan, asal bisa menghasilkan uang, salah satunya yaitu sebagai tukang tandur ${ }^{1}$ yang bekerja secara kelompok. Ia ingin mengabdi kepada keluarganya dan menunjukkan bahwa walaupun berstatus janda, dia bukan beban bagi keluarganya. Seharusnya melalui 
kerja keras tersebut, Simbah dapat memandang Sayem sebagai pribadi yang utuh dan independen.

\subsubsection{Kekerasan Psikis}

Tidak pernah melakukan tindak kekerasan fisik, bukan berarti Simbah tidak melakukan kekerasan psikis. Simbah justru beberapa kali melakukan tindak kekerasan psikis yang menyebabkan Sayem ketakutan, tidak berdaya, bahkan hilangnya kemampuan untuk bertindak. Simbah memaksa Sayem menikah dengan Tugiman Blanggreng walaupun Sayem mati-matian menolaknya. Simbah seolah mempunyai kekuatan untuk mengatur hidup Sayem. Hal ini terbukti dengan tetap berjalannya pernikahan tersebut walaupun Sayem tak menghendakinya. Bahkan saat perkawinan tersebut gagal Sayem tak mampu menolak perintah Simbah saat menjodohkannya kembali dengan Suparno.

Tindakan Simbah tersebut pun diperkuat dengan prinsip hidup orang Jawa menurut Hildred Geertz (1985: 59) yang mengatakan bahwa di tengah-tengah keluarga Jawa, kenyataannya anak harus menyerahkan pemilihan jodoh kepada orang tua. Ini merupakan pertanda tentang ketergantungan sosial dan psikis seorang anak kepada orang tuanya, tentang penerimaannya terhadap tanggung jawab di masa mendatang untuk orang tuanya pada hari-hari tua mereka, serta tentang status anak yang lebih rendah dari orang tua. Prinsip tersebut pulalah yang dipegang oleh Simbah. Ia berpendapat bahwa sebelum menikah Sayem adalah tanggung jawabnya, sedangkan setelah menikah Sayem adalah tanggung jawab suaminya.

\subsubsection{Kekerasan Seksual}

Simbah memang bukanlah pelaku utama dalam kekerasan seksual. Namun, secara tidak langsung Simbah telah melakukan tindak kekerasan seksual melalui perantara suami Sayem. Pada suami pertama, Simbah menyuruh Sayem untuk menemani suaminya tidur dan tidak memperbolehkan Sayem untuk tidur bersamanya lagi. Secara tidak langsung hal itu merupakan perintah halus untuk melayani suaminya di ranjang. Namun, ternyata Sayem tak mampu untuk menuruti kemauan Simbah dan Tugiman Blanggreng karena ia merasa tidak dapat mencintai suaminya tersebut hingga akhirnya ia bercerai.
Hal serupa pun terjadi ketika Sayem menikah dengan Suparno. Sayem yang langsung dibawa ke rumah Suparno pun akhirnya mau melayani Suparno di ranjang. Namun, hal tersebut bukanlah berdasarkan kemauannya sendiri. Ini merupakan sebuah bentuk pengorbanan besarnya terhadap Simbah. Jika Sayem tidak melayani suaminya di ranjang, perceraian tersebut pun pasti akan terulang dan Sayem harus menerima kemarahan Simbah kembali. Oleh karena itu, kini ia rela mengorbankan dirinya sebagai alat kepuasan seksual suami keduanya. "Aku benar-benar mengucap syukur ketika segala siksaan itu akhirnya berakhir dengan dengusan panjang napas suamiku. Dalam hati aku bertanya, "Gusti, apakah Engkau melihat apa yang telah aku korbankan untuk orang lain? Sebuah siksaan batin yang luar biasa," (hlm. 178).

\subsection{Menantu}

\subsubsection{Marginalisasi}

Peminggiran ini terlihat ketika mertuanya menyuruh Suparno untuk menceraikan Sayem karena ia tidak juga menunjukkan tanda-tanda kehamilan. Dampak pemiskinan kembali dari perceraian itu walaupun tidak dirasakan oleh Sayem, tetapi dapat terlihat oleh masyarakat. Sayem yang semula tinggal di rumah joglo kini harus kembali ke rumahnya yang bahkan hanya terbuat dari anyaman bambu. Hal ini menunjukkan kekerasan ekonomi yang dialami oleh Sayem dalam keluarga tersebut. Kemiskinan Sayem seolah mempermudah mertuanya untuk memperlakukan Sayem dengan semaunya. Ia dengan mudah meminta anaknya untuk menceraikan Sayem karena ia yakin Sayem tak dapat menuntut ataupun melawan keputusan keluarga tersebut yang status sosialnya lebih tinggi daripadanya. Stereotipe yang mengharuskan perempuan melahirkan dan menjadi seorang ibu membuat Sayem harus mengalami marginalisasi dalam keluarga tersebut. Hal ini pun membawa dampak psikis dan seksual tersendiri dalam diri Sayem.

\subsubsection{Stereotipe}

Mertua Sayem memandang posisi wanita atau istri dalam rumah hanyalah sebagai kanca wingking ${ }^{2}$ yang hanya berkutat di sumur, dapur, dan kasur. Prinsip 
tersebut memperlihatkan kedudukan Sayem dalam rumah tersebut yang hanya berkutat di wilayah domestik. Mertua Sayem membatasi ruang gerak Sayem dalam sektor publik karena baginya perempuan merupakan sosok yang harus ada di rumah dan melayani keluarganya sepanjang hari. Ketika Sayem bertindak kurang sesuai dengan stereotipenya tersebut, mertua Sayem langsung memarahinya tanpa berani Sayem bantah. Stereotipe yang dituntut mertuanya terhadap pribadi Sayem membuatnya tidak mampu bertindak sesuai dengan keinginan hatinya. Artinya, Sayem telah kehilangan hak untuk melakukan hal-hal ataupun perbuatan-perbuatan yang dinginkannya dalam keluarga tersebut.

Prinsip kanca wingking belum dapat dipenuhi Sayem. Sumur dan dapur memang dapat dilaksanakan oleh Sayem. Namun, kasur yang berarti melayani suami di ranjang dan juga memberikan keturunan belum dapat dilaksanakan Sayem dengan sempurna. Ia memang dapat melayani Suaminya di ranjang, tetapi belum dapat memberikannya keturunan. Persepsi masyarakat seolah membebani perempuan dengan ekspektasi tinggi untuk menjadi seorang ibu. Padahal, menjadi ibu merupakan hak setiap perempuan, bukan kewajiban. Perempuan berhak atas hak independen tubuhnya sendiri, begitu juga dengan laki-laki. Namun, oleh masyarakat, fungsi reproduksi perempuan - sebagai hak individu perempuanseolah dilegitimasi sebagai hak bersama (Arivia, 2006: 462). Itu pulalah yang terjadi dalam diri Sayem. Ia diharuskan hamil dan melahirkan cucu baru untuk keluarga tersebut. Hal ini memperlihatkan bahwa Sayem juga mengalami kekerasan seksual yang ditandai oleh pemaksaan kehamilan terhadap diri seorang perempuan seperti yang dijelaskan di atas.

\subsubsection{Subordinasi}

Mertua Sayem merupakan ciri perempuan Jawa yang mensubordinatkan golongannya sendiri. Baginya dan adat yang dianut dalam rumah tersebut, laki-laki memiliki kedudukan yang lebih tinggi dibanding perempuan, sekalipun ibu kandung maupun istrinya sendiri. Hal itu terlihat dari pemberian jatah makanan yang berbeda antara laki-laki dan perempuan. Lakilaki mendapat jatah nasi putih tanpa dicampur, sedangkan perempuan mendaptkan nasi yang telah dicampur oleh tiwul (hlm. 183). Hal ini disebabkan oleh persepsi laki-laki yang bekerja lebih berat daripada perempuan.

Konsepsi garwa (istri) bukan sekadar kanca wingking, melainkan juga diartikan sebagai sigaraning nyawa (belahan jiwa atau separuh dari jiwa) merupakan salah satu solusi yang tepat untuk mengurangi kesubordinatan pada perempuan. Makna sigaraning nyawa ini tampak jelas memberi gambaran posisi yang sejajar dan lebih egaliter daripada kanca wingking (Handayani dan Novianto, 2004: 120) sehingga perempuan tidak hanya diartikan sebagai sumur, dapur, dan kasur, tetapi juga sebagai satu kesatuan utuh yang saling melengkapi.

\subsubsection{Kekerasan Ekonomi}

Kekerasan ekonomi yang dilakukan mertua Sayem terhadap dirinya yaitu pengeksploitasian tenaga kerja. Selama Sayem tinggal di rumah tersebut, ia lebih mirip seperti pekerja kasar yang hanya bertugas memasak dan membereskan rumah daripada seorang menantu. Tenaga Sayem benar-benar diperas di rumah itu. Bahkan ia tidak memiliki hak suara sama sekali sebagai menantu. Di sana, kewajibannya hanya berbakti kepada suami dan mertuanya.

\subsubsection{Kekerasan Fisik}

Pemberian jatah makanan yang berbeda antara laki-laki dan perempuan memberikan dampak kekerasan fisik terhadap Sayem. Ia terpaksa harus mengikuti tradisi tersebut walaupun tidak menyukainya sama sekali. Sayem sudah sangat memaksakan untuk memakan nasi kombinasi tersebut, tetapi mulutnya tak mampu menerima sehingga sehari-hari ia hanya makan singkong rebus. Kebiasaan tersebut pun membuatnya jatuh sakit.

\subsubsection{Kekerasan Psikis}

Pengawasan yang ketat terhadap setiap sikap dan perilaku Sayem selama di rumah tersebut membuat Sayem merasa ketakutan dan tak berdaya. Ibarat seorang juri, mertua Sayem selalu memberikan nilai terhadap setiap pekerjaan yang Sayem lakukan. Ketegangan yang terjadi antara Sayem dan mertuanya sudah terjadi sejak awal Sayem tinggal di rumah tersebut, tepatnya ketika Sayem terlambat bangun di pagi hari. Bagi orang Jawa, perempuan haruslah 
bangun sebelum ayam berkokok karena banyak tugas yang harus dikerjakan oleh perempuan di pagi hari.

Ketegangan pun semakin terasa ketika mertuanya meminta Suparno menceraikan Sayem. Pukulan berat yang harus Sayem terima itu, berdampak terhadap psikisnya. Setelah perceraiannya tersebut, Sayem berubah menjadi sosok yang pendiam dan takut terhadap laki-laki. Dampak dari kekerasan tersebut tidak hanya Sayem rasakan selama di rumah tersebut, tetapi juga saat ia sudah tak berada di rumah itu lagi.

\subsubsection{Kekerasan Seksual}

Berbeda dengan Simbah, mertua Sayem tidak pernah memaksa Sayem untuk melayani suaminya di ranjang. Namun, secara tidak langsung mertua Sayem pun melakukan kekerasan seksual yang sama. Mertua Sayem seolah memiliki hak legitimasi yang sama mengenai alat reproduksi Sayem. Ia menuntut agar Sayem segera hamil dan melahirkan. Jika Sayem tak juga menunjukan tanda-tanda kehamilan, mertua Sayem menyuruh Suparno untuk menceraikan Sayem.

\subsection{Istri}

\subsubsection{Tugiman Blanggreng}

Tugiman Blanggreng merupakan suami pertama Sayem yang tidak pernah melakukan tindakantindakan ketidakadilan gender dalam rumah tangga mereka. Hal ini karena usia rumah tangga mereka yang sangat singkat. Mereka hanya tinggal bersama selama tiga hari. Selanjutnya Tugiman Blanggreng kembali ke rumahnya untuk menenangkan diri setelah mendapat penolakan dari Sayem.

"Jangan kamu putuskan segala sesuatu sebelum kamu mencobanya." Rupanya, suamiku tidak mau menyerah begitu saja. Dia kembali akan keluar kamar untuk menghindari pembicaraanku, tapi aku berhasil mencegahnya.

"Mas, aku mohon jangan pergi dulu. Aku masih ingin bicara padamu. Aku sudah katakan hal yang sejujurnya. Tentunya kita tidak mau kan hidup dalam kepura-puraan? Itu akan menyakiti satu sama lain."

"Terus sekarang apa maumu? Aku harus seperti apa untuk menghadapi perkawinan ini? Apa kita harus cerai secepatnya? Itukah yang kamu inginkan? Atau apa?" (Rahyuningsih, 2011:148-149).

Kutipan di atas menggambarkan bahwa Tugiman Blanggreng merupakan sosok laki-laki yang terbuka dan mau menerima pendapat Sayem. Ia tidak pernah memaksakan Sayem untuk melanjutkan perkawinan mereka. Bahkan ia cenderung menyerahkan semua keputusan pada Sayem. Ia benar-benar menampilkan tipikal laki-laki Jawa yang tenang, terkontrol, dan tidak suka berkonflik (Handayani dan Novianto, 2004:125).

\subsubsection{Suparno}

\subsubsection{Marginalisasi}

Ketika akan diceraikan oleh Suparno, Sayem hanya dianggap sebagai gadis miskin yang dapat dibeli dan dibuang dengan seenaknya. Bungkusan berupa kebaya dan jarit baru digunakan sebagai pelicin agar Sayem menyetujui rencana perceraian tersebut. Perbedaan status sosial yang terjadi di antara Sayem dengan mertuanya membuat mertua Sayem tidak dapat berlaku andhap-asor terhadap Sayem. Justru sebaliknya, Sayem yang harus berkelakuan andhap-asor atau mengalah terhadap orang yang kedudukannya lebih tinggi walaupun harga dirinya diinjak-injak. Hal ini memperlihatkan bahwa kaum marginal seperti Sayem sangat rentan mengalami kekerasan ekonomi.

\subsubsection{Stereotipe}

Suparno ialah sosok laki-laki yang perhatian dan sangat mencintai istrinya, Sayem. Ia pun tak pernah membedakan antara laki-laki dan perempuan. Ia tak pernah memberikan label khusus pada Sayem sebagai seorang istri layaknya mertua Sayem. Ia juga tak pernah berpikiran bahwa laki-laki memiliki derajat yang lebih tinggi daripada perempuan. Oleh karena itu, ia setuju dengan pendapat Sayem mengenai penyamarataan jatah makanan di rumah antara lakilaki dan perempuan. Bahkan Suparno ialah orang yang cenderung menurut terhadap ibunya yang merupakan golongan perempuan.

Ketidakberdayaan Suparno terhadap ibunya menunjukkan bahwa keluarga ini sangat menganut sistem terminologi jawa menurut Geertz (1983: 19) yang memiliki semacam dualitas pemisah yang fundamental antara kiri dan kanan serta sepuh dan nem (tua dan muda). Oleh karena itu, walaupun kedudukan laki-laki cukup tinggi dalam keluarga, jika 
ia masih tinggal bersama dengan orangtua, ia akan tetap terkalahan oleh orangtuanya tersebut.

\subsubsection{Subordinasi}

Suparno memang tidak pernah menganggap posisi Sayem lebih subordinat daripada dirinya. Namun, saat Simboknya menganggap bahwa posisi perempuan lebih subordinat daripada laki-laki, Suparno pun tak mampu berbuat apa-apa sehingga secara tidak sadar pun suparno telah memosisikan Sayem dalam keadaan subordinat. Dalam keadaan inilah timbul kekerasankekerasan yang dialami Sayem dalam rumah tangga mereka.

\section{a. Kekerasan Fisik}

Kekerasan fisik yang dialami oleh Sayem berkaitan erat dengan kekerasan seksual. Hal ini disebabkan, kekerasan fisik tersebut timbul akibat adanya kekerasan seksual yang dilakukan oleh Suparno. Sayem merasa sakit saat melakukan hubungan seksual. Tak ada kenikmatan dalam hubungan tersebut karena Sayem pun melakukannya dengan penuh tekanan dan ketakutan sehingga yang dihasilkan hanya rasa sakit pada tubuhnya. Sayem menganggap hubungan seksual tersebut hanya merupakan kewajiban semata yang harus dijalankan, padahal hubungan seksual dalam rumah tangga sebenarnya adalah hak dari setiap pasangan karena menurut Darwin dalam buku Kekerasan terhadap Perempuan kepuasan seksual merupakan salah satu faktor penentu dalam kehidupan rumah tangga (Djannah, 2003:45).

\section{b. Kekerasan Psikis}

Sebenarnya, Suparno tidak pernah melakukan tindak kekerasan psikis terhadap Sayem atas kemauannya sendiri. Kekerasan psikis hanya dilakukan oleh mertua Sayem, tetapi melalui perantara Suparno, seperti yang terlihat ketika Suparno harus menceraikan Sayem. Suparno pun sebenarnya merasakan sakit yang sama. Ia pun sebenarnya tidak menginginkan perceraian tersebut. Namun, karena posisinya yang lebih subordinat daripada ibunya, ia harus menuruti kemauan ibunya tersebut.

\section{c. Kekerasan Seksual}

Seks menjadi salah satu kewajiban yang harus dijalankan Sayem dalam perkawinannya dengan Suparno. Namun, kewajiban tersebut sebenarnya tak ingin Sayem jalankan. Bahkan saat melakukan hubungan intim dengan suaminya tersebut Sayem merasa sangat ketakutan dan sedih. Namun, ia tak juga dapat menolaknya karena ini merupakan sebuah bentuk pengorbanan yang dapat ia lakukan sebagai seorang cucu dan istri yang baik.

Suparno sebenarnya tidak pernah memaksa Sayem untuk melakukan hubungan intim, tetapi Suparno tidaklah peka dalam membaca situasi. Ia tidak melihat ketakutan dan keengganan dari sikap Sayem saat melayaninya tersebut. Tidak adanya kenikmatan yang dirasakan oleh salah satu pihak dalam sebuah hubungan intim yang sedang dilakukaan merupakan tanda-tanda kekerasan seksual, seperti yang diungkapan oleh Fathul Djannah (2003: 45) bahwa pemaksaan dan ketidakacuhan terhadap hasrat dan kepuasan seksual pasangan merupakan salah satu bentuk kekerasan seksual sehingga dapat disimpulkan bahwa Sayem mengalami kekerasan seksual yang dilakukan oleh Suparno.

\subsubsection{Priyo}

\subsubsection{Marginalisasi}

Priyo dan Sayem merupakan dua orang yang memiliki perbedaan status sosial yang jauh. Priyo ialah seorang keturunan priayi yang bekerja di kantor kelurahan, sedangkan Sayem hanyalah rakyat biasa yang bekerja sebagai sinden. Namun, ternyata perbedaan sosial tersebut tak menghalangi cinta di antara mereka. Sayem yang hanya berasal dari golongan marginal merasa sangat beruntung bersuamikan Priyo. Priyo pun bukan merupakan sosok laki-laki yang memandang rendah seorang perempuan berdasarkan status sosialnya.

Dalam novel ini, Dwi Ranhyuningsih menggambarkan kebahagiaan dan kebanggaan Sayem yang luar biasa setelah bersuamikan Priyo. Baginya, Priyo merupakan perantara Tuhan yang mengangkatnya dari kegelapan masa lalunya.

Ketika aku kembali mengingat masa laluku yang pedih, betapa aku tak pernah menyangka apa yang aku dapatkan saat ini. Semua itu aku sadari berkat Mas Priyo. Tanpa 
bersuamikan dia, aku tak mengecap apa yang kurasa sekarang ini. Anak-anak yang manis, pengakuan orang lain akan keberhasilanku dalam mendampingi anak, dan penghidupan yang cukup rasanya mustahil dicapai oleh perempuan yang hanya bersekolah hingga kelas dua SR sepertiku (Rahyuningsih, 2011:381).

Kutipan di atas menggambarkan rasa syukur Sayem memiliki Priyo. Namun, juga menggambarkan ketidakpercayaan ia terhadap dirinya sendiri. Ia merasa semua keberhasilannya tersebut berkat Priyo. Padahal, jauh di balik itu semua, ketegaran, ketulusan, dan kekuatan Sayem sendirilah yang mampu membuatnya mencapai keberhasilannya tersebut. Ia cenderung lebih memandang Priyo daripada dirinya sendiri sehingga ia selalu merasa wajib membalas budi baik Priyo. Bahkan saat Priyo menyakitinya dengan melalaikan tugasnya sebagai suami dan ayah, Sayem tetap menerima Priyo sebagai suaminya. Hal itu disebabkan konsep dalam diri Sayem yang menyatakan bahwa Priyo merupakan penolong yang telah mengangkat derajatnya, sehingga apa pun kesalahan yang Priyo lakukan Sayem harus memaafkannya karena ini merupakan harga yang harus Sayem bayar atas kebahagiaan yang telah Priyo berikan.

\subsubsection{Stereotipe}

Selama menikah, Priyo tidak pernah menuntut Sayem untuk bersikap dan berperilaku layaknya perempuan Jawa apalagi perempuan priyai. Namun, Priyo tetap menginginkan Sayem menjadi istri yang kuat, tabah, dan sabar, dengan kata lain Priyo menstereotipekan agar Sayem dapat bersikap nerima, sabar, dan ikhlas. Tuntutan Priyo tersebut bukanlah tanpa alasan, pertama karena Piyo telah memiliki istri sebelumnya sehingga Sayem haruslah kuat sebagai istri kedua. Kedua, perempuan yang mengelilingi Priyo sangatlah banyak karena Priyo merupakan tipe laki-laki yang mudah bergaul dan perayu yang mudah mendapatkan wanita. Ketiga, Sayem harus menerima dengan sabar dan ikhlas dengan kebiasaan baru Priyo sebagai seorang pemabuk. Hal-hal tersebutlah yang akhirnya memberikan dampak psikis dalam diri Sayem.

Sebagai istri kedua Sayem harus menjadi pribadi yang kuat dan sabar baik menghadapi cibiran orang ataupun perlakukan yang tidak menyenangkan dari istri pertama Priyo karena istri pertama dan istri kedua bagaikan air dan minyak yang sangat sulit untuk bersatu. Selain itu, Sayem pun harus sabar dan ikhlas dalam menghadapai sifat Priyo yang mudah jatuh cinta terhadap seorang sinden hingga akhirnya priyo menikahi sinden-sinden tersebut. Ketiga, dalam mengahadapi kebiasaan baru Priyo yang suka mabukmabukan Sayem harus menampilkan kekuatannya dan kesabarannya dalam merawat Priyo jikalau ia sedang mabuk.

Priyo sebagai seorang laki-laki menuntut agar Sayem menjadi istri yang diinginkannya, sementara itu sebagai seorang perempuan Sayem justru tidak pernah menuntut apapun dalam diri suaminya. Ini membuktikan bahwa pelabelan terhadap perempuan jauh lebih kuat daripada laki-laki. Hal ini pun sejalan dengan konsep wanita dalam bahasa Jawa yang berarti wani ditata atau berani diatur. Artinya, perempuan membiarkan dirinya ditata dalam suatu aturan yang sudah menentukan posisinya berada dan apa saja yang menjadi tanggung jawabnya (Handayani dan Novianto, 2004: 144).

\subsubsection{Subordinasi}

Subordinasi dalam rumah tangga Sayem dengan Priyo sebenarnya tidak terlalu terlihat jelas karena Priyo merupakan laki-laki yang tak pernah memandang rendah atau membeda-bedakan orang berdasarkan jenis kelaminnnya. Bahkan ia tidak pernah digambarkan terlihat memosisikan Sayem sebagai pihak yang tersubordinasikan. Namun, pada kenyataannya bentuk-bentuk kekerasan dalam rumah tangga tetaplah dialami Sayem selama menikah dengan Priyo. Hal ini disebabkan subordinasi yang dimunculkan oleh Priyo berbalut kasih sayang yang menipu.

Salah satu contoh subordinasi tersebut yaitu ketika Sayem mengetahui bahwa Priyo telah memiliki istriistri lainnya yang berasal dari golongan pesinden, Priyo dengan halusnya berkata bahwa ia sangat mengagumi seorang sinden yang berada di atas panggung. Kekaguman itu seolah menguasainya hingga ia tak sadar lagi dengan apa yang dia lakukan. Ketika terjaga, dia sadar bahwa telah berbuat dosa dan mengkhianati Sayem (hlm. 359). Hal itu seolah 
memperlihatkan bahwa Priyo sebenarnya meyakini bahwa ia seorang laki-laki yang mampu menguasai perempuan. Ia yakin, walaupun ia berbuat salah, Sayem pasti akan memaafkannya. Hal ini pun terlihat jelas dengan sikap Priyo yang begitu tenang dan seolah tanpa beban saat Sayem mulai mempermasalahkan kesalahan-kesalahan yang dibuat Priyo.

\section{a. Kekerasan Ekonomi}

Dwi Rahyuningsih menggambarkan beberapa kekerasan ekonomi yang dilakukan oleh Priyo terhadap Sayem di antaranya, pengeksploitasian tenaga kerja dan melalaikan tugasnya sebagai kepala keluarga sehingga Sayem harus bekerja banting tulang untuk menafkahi keluarga. Awalnya, Priyo merupakan sosok suami yang sangat mendukung pekerjaan istrinya sebagai pesinden. Namun, lamakelamaan hal ini seolah terlihat sebagai pengeksploitasian tenaga kerja terhadap istrinya sendiri. Salah satu alasan Priyo mabuk-mabukan dan selalu ikut dalam setiap pagelaran karawitan adalah agar Sayem lebih dikenal sebagai seorang sinden dan menerima banyak pekerjaan dari orang-orang tersebut.

Kekerasan tersebut pun semakin diperparah ketika priyo telah menikah dengan perempuan-perempuan lainnya. Priyo semakin melalaikan tugasnya sebagai pemberi nafkah dalam keluarga sehingga Sayem pun harus bekerja lebih keras lagi sebagai pesinden agar dapat menghidupi anak-anaknya karena kini Priyo harus membagi gajinya kepada empat orang istrinya. Sayem pun harus mengajarkan sikap hidup hemat kepada anak-anaknya seperti yang Simbah ajarkan dahulu kepadanya. Perubahan situasi dan kondisi tersebut merupakan faktor utama terjadinya kekerasan ekonomi yang dialami oleh Sayem.

\section{b. Kekerasan Fisik}

Pada dasarnya Priyo ialah sosok laki-laki yang lembut dan welas asih sehingga ia tak mungkin melakukan tindak kekerasan fisik. Namun, saat Priyo mabuk, tanpa sadar beberapa kali ia telah melakukan kekerasan fisik terhadap Sayem. Contohnya saat Sayem pulang menyinden sore hari, beberapa kali ia mendapati suaminya telah terkulai lemas di kursi karena mabuk. Dalam kondisi kecapaian dan hamil muda, Sayem masih harus mengurus suaminya yang muntah-muntah dan mengigau tak keruan. Padahal, saat hamil muda tersebut Sayem sangat tidak kuat dengan bau alkohol (hlm. 337). Hal tersebut menunjukkan kekerasan fisik yang dialami Sayem. Bahkan karena terlalu kecapaian dan banyak beban pikiran Sayem sampai harus rela kehilangan anak pertamanya.

\section{c. Kekerasan Psikis}

Kekerasan psikis yang dialami Sayem sebagian besar karena sifat Priyo yang gemar menikah. Hal tersebut membuat Sayem sulit berkomunikasi dan bertemu dengan Priyo, bahkan saat ia membutuhkan dukungan moril maupun materil dari seorang suami Priyo tak pernah sempat mendampinginya. Ketika Sayem rindu dan membutuhkan teman berbicara pun ia harus membunuh perasaannya sendiri karena ia tidak ingin mengganggu Priyo yang sedang bersama istri pertamanya. Sikap mengalah sayem sebagai istri kedua membuatnya banyak memendam perasaannya sendiri. Padahal seharusnya, jika Priyo berani mengambil keputusan untuk memiliki dua orang istri, ia pun harus siap membagi waktu, cinta, dan uangnya dengan seadil-adil mungkin agar tidak terjadi pendiskriminasian terhadap salah satu pihak.

Kekerasan psikis yang mendera Sayem semakin terasa ketika ia harus menerima kenyataan bahwa suaminya menikah lagi dengan dua orang pesinden dalam waktu yang hampir berdekatan. Pesinden seolah mempunyai magnet tersendiri dalam menarik hati Priyo untuk berpoligami. Poligami sendiri menurut Geertz (1985:136) merupakan simbol tingginya kedudukan pria. Hal ini menyimbolkan bahwa pria yang mampu berpoligami adalah pria hebat yang dapat menaklukan hati para wanita dan hanya pria hebat yang dapat mengatur waktu, cinta, dan uangnya untuk beberapa wanita tanpa menimbulkan keributan.

\section{SIMPULAN}

Penggambaran tokoh-tokoh yang berada di bagian kanan dan/atau bawah pada sitem terminologi Jawa memiliki kecenderungan lebih subordinat daripada 
Anita Rima Dewi: Kedudukan Perempuan Jawa dalam Novel Hati Sinden Karya ...

tokoh yang berada di kiri dan/atau atas. Seperti yang

digambarkan pada tabel di bawah ini.

\begin{tabular}{|c|c|c|c|c|}
\hline \multicolumn{5}{|c|}{ Kerangka Garis Besar Tata Istilah Keluarga Sayem } \\
\hline \multicolumn{3}{|c|}{ Istilah Keluarga } & Di Rumah Simbah & Di Rumah Mertua \\
\hline $\begin{array}{l}\text { Turun ke } \\
\text { atas kedua }\end{array}$ & Nenek & 1 simbah & & \\
\hline $\begin{array}{ll}\text { Turun ke } \\
\text { atas } \\
\text { pertama }\end{array}$ & ibu mertua & 2 simbok & & \\
\hline $\begin{array}{l}\text { Seturunan } \\
\text { diri }\end{array}$ & $\begin{array}{l}\text { suami pertama } \\
\text { suami kedua } \\
\text { suami ketiga } \\
\text { diri }\end{array}$ & $\begin{array}{ll}\text { 3a } & \text { Tugiman Blanggreng } \\
\text { 3b } & \text { Suparno } \\
\text { 3c } & \text { Priyo } \\
4 & \text { Sayem }\end{array}$ & $\underset{3 \mathrm{a} ; 3 \mathrm{c}, 4}{7}$ & $3 b, 4$ \\
\hline
\end{tabular}

Dari tabel di atas dapat terlihat bahwa Sayem merupakan orang yang memiliki kedudukan paling rendah, sedangkan Simbah dan mertua Sayem menempati posisi paling atas dalam keluarga masingmasing. Hal ini menyatakan bahwa kedudukan tertinggi dalam terminologi Jawa tidak selalu diduduki oleh laki-laki. Kedudukan antara Sayem dengan Simbah dan Mertua Sayem tersebut menggambarkan bahwa perempuan merupakan golongan subordinat yang juga dapat berubah menjadi golongan superordinat. Artinya perempuan tidak hanya dapat dikuasai, tetapi juga dapat berkuasa.

Setelah menyimpulkan posisi kedudukan dari tiap tokoh, penulis membuat kesimpulan mengenai kedudukan Sayem dengan lebih dalam melalui perspektif gender.

\begin{tabular}{|c|c|c|c|c|c|c|c|c|c|c|c|c|}
\hline \multirow{3}{*}{$\begin{array}{c}\text { Kedudukan Sayem } \\
\text { dalam Keluarga }\end{array}$} & \multicolumn{4}{|c|}{ Marginalisasi } & \multicolumn{4}{|c|}{ Stereotipe } & \multicolumn{4}{|c|}{ Subordinasi } \\
\hline & \multirow[t]{2}{*}{ Eko } & \multicolumn{3}{|c|}{ Kekerasan } & \multirow[t]{2}{*}{ Eko } & \multicolumn{3}{|c|}{ Kekerasan } & \multirow[t]{2}{*}{ Eko } & \multicolumn{3}{|c|}{ Kekerasan } \\
\hline & & $\mathrm{F}$ & $\mathrm{P}$ & $\mathrm{S}$ & & $\mathrm{F}$ & $\mathrm{P}$ & S & & $\mathrm{F}$ & $\mathrm{P}$ & $\mathrm{S}$ \\
\hline Cucu & + & - & + & - & + & - & + & - & + & - & + & + \\
\hline Menantu & + & - & + & + & - & - & + & + & + & + & + & + \\
\hline Istri 1 & - & - & - & - & - & - & - & - & - & - & - & - \\
\hline Istri 2 & + & - & + & - & - & - & - & - & - & + & + & + \\
\hline Istri 3 & + & - & + & - & - & - & + & - & + & + & + & - \\
\hline
\end{tabular}

Tabel di atas memperlihatkan bahwa setiap kedudukan Sayem dalam keluarga baik sebagai cucu, menantu, maupun istri selalu menerima ketidakadilan gender. Saat ia menjadi cucu, ia mendapat ketidakadilan gender dari Simbahnya dan saat ia menjadi seorang menantu sekaligus istri ketidakadilan gender juga tetap membelenggunya. Perubahan perannya dalam keluarga tidak serta-merta mengubah posisinya menjadi lebih baik. Justru ia semakin terpuruk karena ketidakadilan gender yang ia dapatkan dari berbagai pihak secara bersamaan. Hidup Sayem seolah hanya sebuah pengabdian dan pengorbanan seperti yang selalu Simbah dan Simboknya tanamkan sedari kecil.

Namun, kedekatan emosional dan rasa sayang merupakan dua faktor yang memengaruhi pola pengabdian Sayem terhadap tokoh-tokoh tersebut. Simbah dan Priyo merupakan dua orang yang memiliki kedekatan emosional yang lebih besar daripada tiga tokoh lainnya. Selain itu, Sayem juga memiliki rasa sayang yang lebih besar terhadap keduanya sehingga pengabdian dan pengorbanan yang Sayem lakukan terhadap keduanya juga jauh lebih besar, lebih lama, dan lebih ikhlas karena balutan kasih sayang dibandingan dengan tiga tokoh lainnya. Tokoh Tugiman Blanggreng merupakan tokoh yang tidak pernah memberikan ketidakadilan gender terhadap Sayem. Hal ini disebabkan umur perkawinan mereka yang sangat cepat, yaitu tiga hari. Sayem pun tidak melakukan pengorbanan yang cukup banyak bagi Tugiman Blanggreng. Pengorbanan Sayem pada Tugiman Blanggreng hanya terjadi ketika awal 
Anita Rima Dewi: Kedudukan Perempuan Jawa dalam Novel Hati Sinden Karya ...

pernikahan mereka. Itu pun karena paksaan Simbah, sedangkan pengorbanan dan pengabdian yang Sayem lakukan terhadap Suparno dan Simboknya hanya ia lakukan selama tinggal di rumah tersebut. Itu pun Sayem sempat melakukan protes mengenai penjatahan makanan yang menurutnya tidak berperikemanusiaan. Kedudukan Sayem yang selalu berada di bawah atau subordinat menimbulkan ketidakadilan gender pada setiap kedudukan yang ia jalani seperti saat ia berada dalam posisi sebagai cucu, menantu, maupun istri.

\section{DAFTAR PUSTAKA}

Adrina, dkk. 1998. Hak-Hak Reproduksi Perempuan yang Terpasung. Jakarta: Pustaka Sinar Harapan.

Arivia, Gadis. 2006. Feminisme: Sebuah Kata Hati. Jakarta: Penerbit Kompas.

Bahsin, kamla. 2001. Memahami Gender. (terj. Moh, Zaki Hussein). Jakarta: Teplok Press.

Damono, Sapardi Djoko. 1984. Sosiologi Sastra: Sebuah Pengantar Ringkas. Jakarta: Pusat Pembinaan dan Pengembangan Bahasa Departemen Pendidikan dan Kebudayaan.

Djannah, Fathul, dkk. 2003. Kekerasan terhadap Istri. Yogyakarta: LKiS.

Dwi Rahyuningsih. 2011. Hati Sinden. Yogyakarta: Diva Press.

Fakih, Mansour. 1997. Analisis Gender dan Transformasi Sosial. Jakarta: Pustaka Pelajar.

Foulcher, Keith. 1991. Pujangga Baru. Terj. Sugiarta Sriwibawa. Jakarta: Girimukti Pusaka.

Handayani, Christina S. dan Ardhian Novianto. 2004. Kuasa Wanita Jawa. Yogyakarta: LKiS.

Ismunandar K., R. 1993. Joglo: Arsitektur Rumah Tradisional Jawa. Semarang: Dahara Prize.

Kenny, William. 1966. How to Analyze Fiction. New York: Monarch Press.

Koentajaraningrat. 1984. Kebudayaan Jawa. Jakarta: Balai Pustaka.

Mahayana, Maman S. 2005. Jawaban Sastra Indonesia, Sebuah Orientasi Kritik. Jakarta: Bening Publishing.

Mantik, Maria Josephine Kumaat. 2006. Gender dalam Sastra: Studi Kasus Drama Mega-Mega. Jakarta: Wedatama Widya Sastra.

Mulder, Niels. 2001. Mistisme Jawa. Yogyakarta: LKiS.

Murniati, A. Nunuk P. 2004. Getar Gender. Magelang: Yayasan Indonesia Tera.

Nugroho, Fentiny. 2000. "Kekerasan terhadap Perempuan dalam Keluarga: Sebab dan Dampak" dalam Kumpulan Karangan untuk Prof. Tapi Omas Ihromi: Benih Bertumbuh. Yogyakarta: Yayasan Galang.

Nurgiyantoro, Burhan. 1995. Teori Pengkajian Fiksi. Yogyakarta: Gajah Mada University Press.

Rosyadi, Imron. 2010. R.A. Kartini: Biografi Singkat 1879-1904. Yogyakarta: Garasi House Of Book.

Sadli, Saparinah. 2010. Berbeda tetapi Setara, Pemikiran tentang Kajian Perempuan. Jakarta: Kompas.

Sihite, Romany. 2007. Perempuan, Kesetaraan, dan Keadilan: Suatu Tinjauan Berwawasan Gender. Jakarta: PT Raja Grafindo Persada.

Siregar, Bakri. 2000. "Telah lahir Suatu Angkatan” dalam Sejarah Sastra Indonesia Abad XX. Jakarta: KPG (Kepustakaan Populer Gramedia).

Situmorang, Elias. “Memahami Ideologi Jender”. Kompas 4 Juli 2008, hlm. 42. 
Anita Rima Dewi: Kedudukan Perempuan Jawa dalam Novel Hati Sinden Karya ...

Sudjiman, Panuti. 1988. Memahami Cerita Rekaan. Jakarta: Pustaka jaya.

Sundari, Sri Sasongko. 2009. Konsep dan Teori Gender. Pusat Pelatihan Gender dan Peningkatan Kualitas Perempuan.

\section{CATATAN BELAKANG}

1) menanam padi dengan sistem manual, yaitu berjalan mundur.

2) kanca 'teman'; wingking 'belakang', jadi artinya istri sebagai teman bagi suami yang tempatnya di belakang. Istilah "belakang" juga identik dengan "dapur". 